\title{
Luther's English Connection: The Reformation Thought of Robert Barnes and William Tyndale
}

James Edward McGoldrick

Cedarville University

Follow this and additional works at: https://digitalcommons.cedarville.edu/faculty_books

Part of the Christianity Commons, History of Christianity Commons, Nonfiction Commons, and the Religious Thought, Theology and Philosophy of Religion Commons

\section{Recommended Citation}

McGoldrick, James Edward, "Luther's English Connection: The Reformation Thought of Robert Barnes and William Tyndale" (1979). Faculty Books. 86.

https://digitalcommons.cedarville.edu/faculty_books/86

This Book is brought to you for free and open access by DigitalCommons@Cedarville, a service of the Centennial Library. It has been accepted for inclusion in Faculty Books by an authorized administrator of DigitalCommons@Cedarville. For more information, please contact digitalcommons@cedarville.edu. 


\title{
Luther's English Connection: The Reformation Thought of Robert Barnes and William Tyndale
}

\author{
Disciplines \\ Christianity | History of Christianity | Nonfiction | Religious Thought, Theology and Philosophy of Religion \\ Publisher \\ Northwestern Publishing House \\ ISBN \\ 0810000709
}

This book is available at DigitalCommons@Cedarville: https://digitalcommons.cedarville.edu/faculty_books/86 


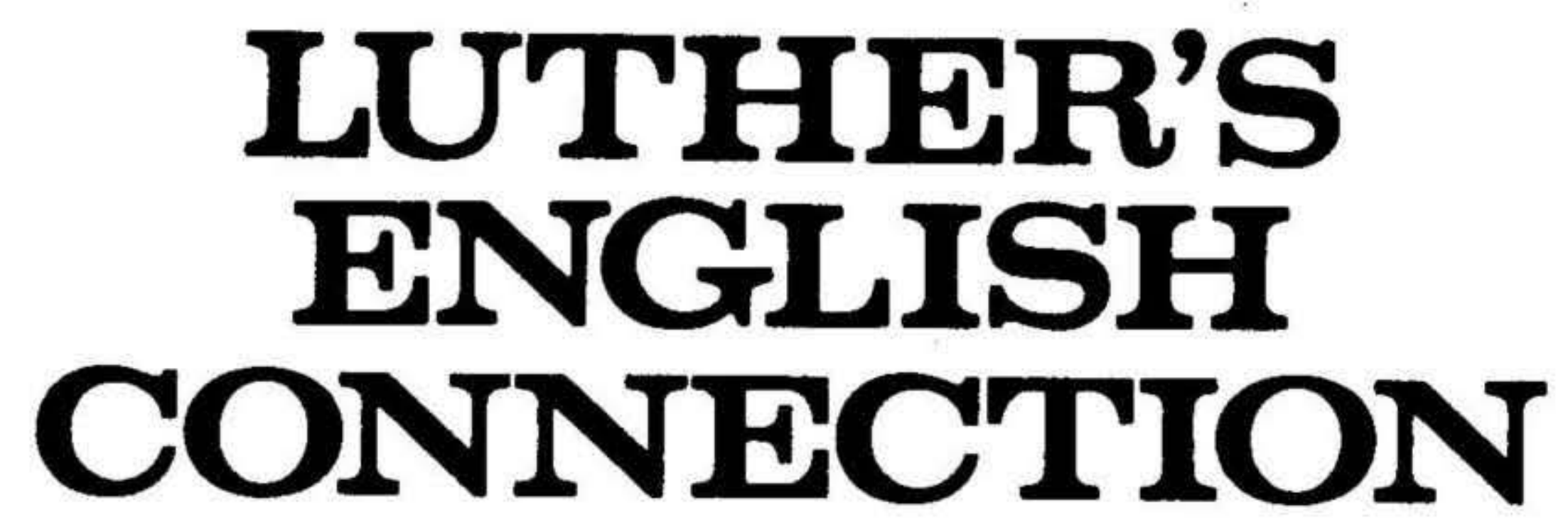

The Reformation Thought

Of Robert Barnes and William Tyndale

\section{james edward mcgoldrick}

Illustrated by Roy Behrens

and $\mathrm{K}$. Dyble Thompson

Northwestern Publishing House

Milwaukee, Wisconsin 


\section{PREFACE}

Until rather recently almost all writers on the relationship between the English and Continental Reformations assumed that Robert Barnes and William Tyndale were key figures in the transmission of Luther's theology to the British Isles. Most books which dealt with this subject categorically stated that Barnes and Tyndale were Protestant theologians of a basically Lutheran persuasion. In the second half of the 20th century, however, a few scholars have recognized that the traditional view of Barnes and Tyndale had never been adequately documented, and, consequently, they have proposed a reinterpretation which holds that these two reformers, especially Tyndale, were actully Erasmian humanists for whom morality rather than theology was the chief concern. The present writer's study of the sources has led him to the conclusion that the traditional view is completely valid with regard to Barnes, and, with some qualifications, generally correct for Tyndale as well. In the case of the latter, it is evident that he disagreed sharply with Luther on the meaning and importance of the eucharistic presence, and his method of defending infant baptism was quite different from Luther's. Because of the great importance that Luther attached to the Eucharist, and in view of Tyndale's divergence from that view, it is probably not appropriate to identify Tyndale simply as an "English Lutheran," as we may confidently do with Barnes. A careful contextual study of the sources has, nevertheless, convinced this author that Tyndale agreed with Luther in almost every area of doctrine except the Lord's Supper, and that the English reformer very often stated his position in terms which were characteristically Lutheran. It is the pur- 
pose of the book to re-examine the traditional interpretation, presenting the evidence for it in a systematic, documented form. The conclusion reached supports the traditional position in general, though with some noteworthy exceptions. Such exceptions notwithstanding, both Barnes and Tyndale were vital links in the chain of Luther's English connection. The controversial interpretive literature is reviewed in chapter 5 .

I wish to thank Mr. Howell Heaney and the staff of the Rare Book Department of the Free Library of Philadelphia for allowing me access to most of the original sources on which this study is based. Regrettably, it is now impossible to express appropriate thanks to the one who first suggested this topic. Dr. Carl S. Meyer, Director of the Foundation for Reformation Research, is no longer with us. Of course, thanks are due to my professors in Reformation history, Dr. Elizabeth Hudson and Dr. Mortimer Levine, whose splendid teaching and wise counsel have been a source of great encouragement. The helpful suggestions of Dr. Manfred 0 . Meitzen and Dr. Ottomar F. Cypris of the Department of Religious Studies at West Virginia University have also been invaluable. Thanks are also due to Dr. Phillip Edgcumbe Hughes of Westminster Theological Seminary who made several suggestions to improve my work, to my son, James E. McGoldrick, Jr., who reviewed the manuscript and to Mrs. Clara Pack who typed it.

Thanks are likewise due to the Rev. John A. Trapp of Northwestern Publishing House who carefully edited this work and made important suggestions to improve it.

James E. McGoldrick

Cedarville, Ohio 


\section{INTRODUCTION}

\section{THE LEGACY OF LOLLARDY}

More than a century before the appearance of Luther's writings in England, the country was convulsed by the vociferous anticlericalism and unorthodox religious teachings of John Wyclif (d. 1384) and the Lollards. Wyclif and his followers assailed long-standing ecclesiastical corruptions such as clerical immorality, simony and the wealth of bishops who neglected their clerical responsibilities. Wyclif likewise advanced a theory of "Civil Dominion," which called on the secular authorities to deprive negligent and corrupt clerics of their properties.

In the realm of doctrine, Wyclif reacted to papal censures of his anticlericalism by assuming theological positions which assaulted the very heart of the medieval church. He was especially alienated from traditional orthodoxy by the scandal of a divided Christendom when rival popes established competing sees at Rome and Avignon in 1378. After this, Wyclif rejected eucharistic transubstantiation and denied that the sacraments were means of saving grace. In Augustinian fashion, he defined the true Church as the body of those predestined for salvation. The pope he branded as Antichrist.

Wyclif justified these radical departures from established dogma by direct appeal to the Bible, which became for him the supreme authority. In 1382, he rendered the authoritative Scriptures into the English language. ${ }^{1}$ Theologically and ecclesiologically, Wyclif foreshadowed the reformers of the sixteenth century in so many ways that he has often been hailed as the "Morningstar of the Protestant Reformation." 
By the opening of the fifteenth century, the English clergy were able to secure government support in their resistance to heresy, and parliament enacted a law for the arrest and execution of convicted heretics. Persecution decimated the ranks of the Lollards, but adherents to their beliefs were sporadically tried for heresy even into the sixteenth century. The Wyclif translation, as emended by his disciples, remained in circulation long after the Lollards were compelled by persecution to adopt a clandestine existence. ${ }^{2} \mathrm{Lol}$ lard doctrines, such as their denial of transubstantiation and their attacks upon clerical corruption, became pronounced features of Protestant movements of the sixteenth century, and Lollard insistence upon the supreme authority of the Bible foreshadowed the Protestant reformers' demand for sola scriptura. Some Protestants reprinted Lollard tracts and books in order to establish historical precedents for their evangelical doctrines, ${ }^{3}$ and enemies of the Reformation such as Sir Thomas More were quick to charge the Protestants with perpetuating condemned Wyclifite views. ${ }^{4}$

\section{THE METHODOLOGY OF HUMANISM}

Although the Lollards were the obvious precursors of English Protestantism, the Reformation derived its method of scholarship from Catholic humanism. During the fifteenth century, the magnetic allure of the "new learning" in Italy attracted a number of English scholars to study under Italian masters such as Guarino at Ferrara and Vittorino at Mantua. Apparently, Vittorino's school supplied something of a pattern for the foundations of the English public school system, while the work of Guarino attracted the interest of Humphrey, Duke of Gloucester, a generous patron of humanist manuscriptural scholarship. However, most of Guarino's English students did not make humanist 
studies a career. They had civil and/or ecclesiastical positions, which were their first concern, and neo-classical studies were almost a hobby with them. Consequently they did not contribute directly to the emergence of a humanist profession in England.

English humanist learning during the fifteenth century was almost a clerical monopoly, and few clerics saw any great distinction between scholasticism and the new approach to study. They saw the humanist method as a tool for the scholastic study of philosophy and theology. ${ }^{5}$ It was the sixteenth century before humanism in England achieved independent status as an avenue of scholarship. In this century London became the great humanist center where the merchant and professional classes sought the benefits of the new learning to equip themselves for their duties in the state.

Humanists followed Plato in stressing proper education for those who govern, and they proposed a corresponding curriculum and educational methods. From this point forward, through the reign of Elizabeth I, humanist learning was adapted to the service of the state. This civic complexion of humanism in Tudor times is reflected in the government careers of celebrated scholars such as Thomas More, Thomas Starkey and Thomas Elyot.

Although sixteenth century English humanism was civic in orientation, it was by no means exclusively secular. Humanist-clerics also pursued the new learning in the interest of making it an instrument for ecclesiastical reform. The humanist efforts in this direction were initiated by distinguished scholars such as John Colet, who studied first at Oxford and later in Italy. Colet became a close friend of Erasmus, who made five visits to England, beginning in 1499. Some hold that Colet's influence led Erasmus into the 
Introduction

study of the Bible and Christian foundations. ${ }^{6}$ Both of these scholars were openly critical of clerical corruptions. Speaking of Colet, Erasmus observed:

There was no class of persons to whom he was more opposed or for whom he had greater abhorrence than those bishops who acted the part of wolves instead of shepherds, showing themselves off before the people with their guise of sanctity, their ceremonies, benedictions, and paltry indulgences, while at heart they were slaves to the world, that is, to ostentation and gain. ${ }^{7}$

When Colet became Dean of St. Paul's Cathedral during the reign of Henry VII, he adopted the humanist method of Biblical exposition in his preaching. He departed from the customary liturgical practice of building homilies on isolated texts and concentrated instead on expounding entire books of the Bible or connected doctrinal themes such as in the Apostles' Creed. ${ }^{8}$

Dean Colet employed the grammatical-exegetical method, which would be adopted by the major Protestant reformers, and the doctrinal conclusions which he reached were remarkably similar to theirs in certain important points. He shared their Augustinian convictions regarding human depravity and predestination, and there is some evidence that he was inclined toward a view of justification compatible with the later Protestant position. ${ }^{9}$

While at Oxford, Colet urged students to study the Scriptures, and a group of earnest Bible students did develop Magdalen College, of which William Tyndale became a member. ${ }^{10}$ Although Tyndale may not have known Colet personally, it seems certain the legacy of Colet's influence 
was strong at Oxford even after he departed for London to become Dean of St. Paul's.

Evidently, Lollard doctrine and humanist methodology converged to a degree in Colet even before they appeared in Protestant reformers such as Robert Barnes and William

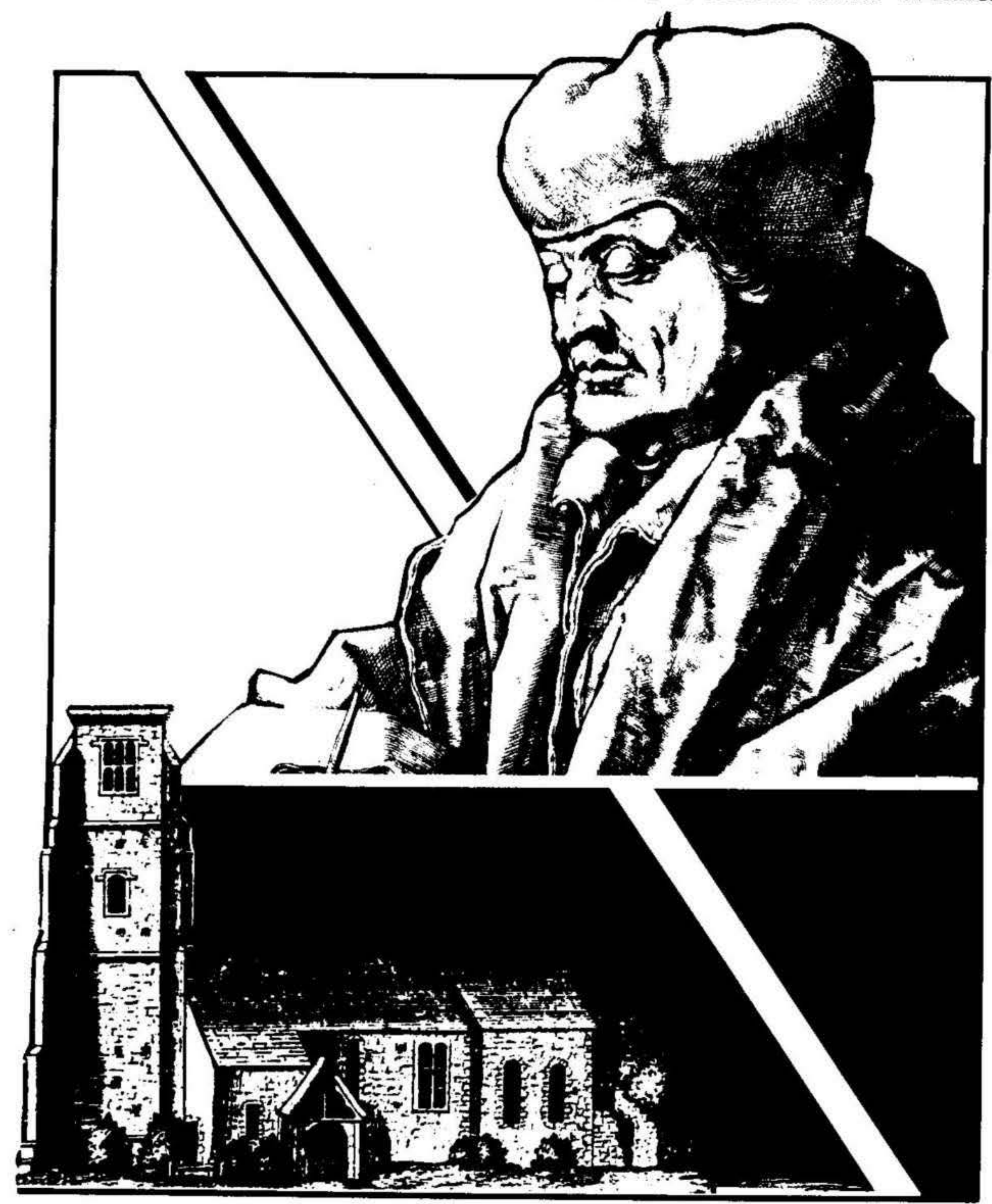

ABOVE: Erasmus of Rotterdam BELOW: the church at Aldington in Kent, England, where Erasmus served as rector in 1511, while he was also delivering lectures at Cambridge. 
Introduction

Tyndale. Colet's preaching excited enthusiasm among Lollards who seemed to regard him as a kindred spirit."11

Furthermore, the Lollard and Protestant demand for Scripture in the vernacular also had parallels among the humanists. In the preface to his 1516 Greek and Latin edition of the New Testament, Erasmus registered his desire to see the Scriptures published in the common tongue:

Would that . . the farmer sing some portion of them at the plow, the weaver hum some parts of them to the movement of his shuttle, the traveller lighten the weariness of the journey with stories of this kind! Let all the conversations of every Christian be drawn from this source. ${ }^{12}$

Although Erasmus did not personally produce a vernacular translation of the Bible, his Greek-Latin New Testament inspired others to do so. Martin Luther used it as the basis for the New Testament portion of his Deutsche Bibel, and Tyndale employed it in his rendering of the New Testament into English. The appearance of Erasmus' New Testament at Cambridge had a quick and heavy impact upon men who were to become the pioneers of the English Reformation. Among them was the Austin prior Robert Barnes.

So it appears that there is a two-fold background against which the thought of the English Protestant reformers should be studied. The first portion is the doctrinal legacy from Wyclif, with whom both Barnes and Tyndale had much in common, and the second is the scholarly methodology of humanism, which both of these reformers broadly and effectively used. 